\title{
FOREWORD: A NEGLECTED DIMENSION OF THE MIDDLE EASTERN (AND WORLD) DILEMMA
}

\author{
Paul R. Ehrlich and Anne H. Ehrlich
}

A scorpion sat by the edge of the Suez Canal. He said to a frog sitting next to him, "Hey, I need to get to the other side. Will you swim me over?" The frog said, "Hah! If I carry you over, you'll sting me and I'll die." The scorpion replied, "Don't be silly. If you die, I'll drown; you'll be perfectly safe." The frog said, "You are right-let's go." Halfway across, the scorpion stung the frog. As the frog went under, he gasped, "Are you nuts? Why did you do it? Now we'll both die." The scorpion replied, "You must remember: this is the Middle East."

This allegory resonates with regard to any number of substantive areas of conflict. It surely is symbolic that both sink because of the excess baggage. Most countries in the Middle East are committing ecological suicide on account of their rapidly growing populations and by ignoring opportunities to cooperate for their mutual benefit.

The area has long been a geopolitical mess, especially since Britain, France, and the United States started interfering there to control energy sources after the Ottoman Empire died. Oil has been at the center of the controversy, and even before Israel formally became a state, petroleum has been a significant node in the mess.

Although the region's conflicts continue, the area's grim environmental future, like that of global civilization, is largely neglected. Ecological conditions are truly dire, but not considered nearly as important as the political situation and access to the region's energy resources. This is especially true of the huge demographic problems that are central to the rapidly darkening prospects for regional sustainability. If there is any glimmer of light, it is this brilliant book by Alon Tal, Israeli environmental scientist and politician. As he has in the past, Tal focuses attention on his nation's ecological predicament-in this case its vast 
overpopulation. He shows that at least some Middle Easterners understand their environmental peril, even if most U.S. politicians in the American empire do not.

Population is often referred to as the "elephant in the room," largely ignored even though it is the biggest driver of civilization toward collapse (overconsumption by the rich is its only competition). Israel has no need of elephants. It is a desert nation, by 2015 home to 8.3 million people, unable to feed itself now, "planning" to increase to about 14 million inhabitants by midcentury. That would take its population density, now nearly twice that of well-watered western Europe, to far beyond that of even the Netherlands. The Palestinian Territory is almost twice as crowded and is also due to double by 2050. Similar grim prospects face most of the rest of Israel's desert neighbors. Despite substantial bloodletting, before the recent civil war Syria was projected to grow 50 percent or more in the next thirty-five years, as are Jordan, Kuwait, Oman, and the United Arab Emirates. Saudi Arabia will come close to that increase, and Iraq will much more than double its numbers. All that growth will be happening in a dryland region short of arable land with chronically scarce water resources!

Besides the biophysical challenges the population situation presents, Israel also faces the demographic challenge of incredible overreproduction by myriad religious and ethnic groups. Many of them contain extreme elements that already threaten peaceful solutions and the country's democratic culture. Should these groups become politically dominant, they could destroy Israel's main advantage in the region: its modern, evidence-oriented culture. Many Israelis have told us they are more afraid of Orthodox extremists than of enemy Arab states. It is not a hopeful sign for the nation that should start taking a sensible approach to its security by establishing peace in the region.

The time in which Israel could move toward sustainability is likely past, but there may still be hope. Its economic dependence on oil is not as direct as that of its Arab neighbors. Israel's high-tech competence, as illustrated by its great advances in agriculture, solar energy, and other areas might allow it to start feeding itself and to help its neighbors do the same-if the population monster could be slain.

Unhappily, however, Israeli politicians and economists have pretty much surrendered to the idiotic notion that economic growth can continue forever. Unless such ideas can be killed locally and globally, the entire point of this essay and, indeed, of this book will become moot.

Suppose instead, someday soon Israel's leaders realize that perpetual growth is the creed of the cancer cell and start to promote population and economic shrinkage, sustainability, efficiency, and equity? Suppose the Israelis stopped 
seeking to assert numeric dominance over their Arab citizens and helped the Palestinians to forge a prosperous future? Jointly, the Israelis and Palestinians might be able to lead their environmentally challenged region toward population reduction and sustainability. They might, as everyone must, leave the past behind them to secure a decent life for their descendants. If such miracles could occur-and many people see Israel as a land of miracles-Israeli citizens might hope to dodge the bullet of collapse, as long as other nations do the same.

Although in terms of geographic and demographic scale Israel is insignificant, it may play the same role in international politics as it has played in advancing desert agriculture. The fate of civilization may even hang on Israel's population situation, which if left unchanged, likely will play an expanding negative role in that nation's behavior. That's why The Land Is Full is such an incredibly important book. 
This page intentionally left blank 